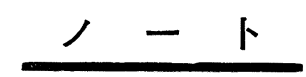

\title{
とうもろこしデンプン製造工程からの 排気ガス中の硫黄化合物の検出
}

\author{
星加安之・小島一郎・小池一美・吉本 健二 \\ 要知県公害調查センター (名古屋市北区辻町流 7-6)
}

\begin{abstract}
Analysis of the Sulfur Compounds in the Exhaust Gases from Two Corn Starch Factories

\author{
Yasuyuki Hoshika, Ichirō Kozıma, Kazumi Korke and Kenji Yoshimoto \\ Aichi Environmental Research Center (Tsuji-machi, Nagare 7-6, Kita-ku, Nagoya)
}

\begin{abstract}
The samples for gas chromatographic analyses of the representative lower sulfur compounds such as carbonyl sulfide, hydrogen sulfide, carbon disulfide, methyl mercaptan and sulfur dioxide in the exhaust gases from two corn starch factories, i.e., an unautomated and an automated factories, were prepared by direct cold trap with liquid oxygen and detected by the flame photometric detector.

The detected concentration ranges and average values of the five representative lower sulfur compounds in the exhaust gas from the unautomated factory were as follows; carbonyl sulfide $0.02 \sim 0.03 \mathrm{ppm}$ (ave. $0.025 \mathrm{ppm}$ ), hydrogen sulfide $0.5 \sim 2.1 \mathrm{ppm}$ (ave. 1.3 $\mathrm{ppm}$ ), carbon disulfide $0.01 \mathrm{ppm}$ (ave. $0.01 \mathrm{ppm}$ ), methyl mercaptan $0.3 \sim 0.6 \mathrm{ppm}$ (ave. $0.45 \mathrm{ppm}$ ), sulfur dioxide $0.1 \sim 0.3 \mathrm{ppm}$ (ave. $0.2 \mathrm{ppm}$ ), or dimethyl sulfide $0.05 \sim 0.1 \mathrm{ppm}$ (ave. $0.075 \mathrm{ppm})$ ).

On the other hand, those from the automated factory were as follows; carbonyl sulfide $0.02 \mathrm{ppm}$, hydrogen sulfide $0.02 \mathrm{ppm}$, carbon disulfide $0.004 \mathrm{ppm}$, methyl mercaptan 0.01 ppm, rather high concentration of sulfur dioxide being $680 \mathrm{ppm}$.
\end{abstract}

\section{1 緒言}

とらもろこしデンプンを製造する際の公害的因子とし ては，おもに粒子状物質が考えられてきた遠心式スクラ バーの設置により, 直火式気流乾燥機から出るガスのデ ンプン粒子に対して生産量 $1 \mathrm{t}$ 当たり $8 \mathrm{lb}$ から $0.02 \mathrm{lb}$ に滅少できたといら報告がある1”。

また, 気体に関するものは乾燥機からの排出ガスを $800^{\circ} \mathrm{C}$ 以上で然焼するといら悪臭除去対策がある ${ }^{2)}$ 。

最近になって, 本業種は悪臭問題をひき起こすことが 知られているが, 製造工程などから排出される気体の組 成に関する内外の報告はほとんど見当たらない。

著者らは, 循環型湿式 密閉法 (浸出液: 亜硫酸水溶 液 $)^{3)}$ による工程から排出される気体成分のうち, 低沸点 硫黄化合物の代表的物質と考えられる, 硫化カルボニ ル, 硫化水素, 二硫化炭素, メチルメルカプタン, 二酸 化硫黄の濃度を明らかにする目的でこの実験を行った。

対象工場は, 自動化の不完全な工場（生産量：とうも ろこしデンプンほか $4,800 \mathrm{t} /$ 年) と完全な工場（同 : $100,000 \mathrm{t} /$ 年）の 2 つを選び, 液体酸素による直接コー
ルドトラップ法を前処理とする迅速なガスクロマトグラ フ分析 によより検討した。

\section{2 実験}

試料採取方法 および装置などは 既報)と同様である が，そのおもなものはつぎのとおりである。

ガスクロマトグラフ : 島津 $\mathrm{GC} 5 \mathrm{AP}_{5} \mathrm{Fp}$

加熱導 入 装 置: 島津 FLS-1

試料採取は日本オゾン（株）製 $1 l$ 試料ガス採取びん で行い, 液体酸素により直接コールドトラップして濃縮 し，ガスクロマトグラフで分析した。

\section{3 結果と考察}

\section{$3 \cdot 1$ 不完全自動化工場排気ガスの分析例}

はい芽分離し(篩)別機 (開放型) 上の排気ガスのガス クロマトグラムの 1 例を Fig.-1 に, 定量結果を Table -1に示した。

その結果, 低沸点硫黄化合物の代表物質と考えられる 硫化カルボニル, 硫化水素, 二硫化炭素, メチルメルカ プタン，二酸化硫黄（または硫化メチル）および $n-フ^{\circ}$ 
ロピルメルカプタンなどを同定した。

検出濃度は平均で, 硫化カルボニル $0.025 \mathrm{ppm}$, 硫化

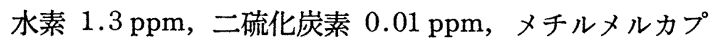
タン $0.45 \mathrm{ppm}$, 二酸化硫黄として $0.2 \mathrm{ppm}$, 硫化メチ

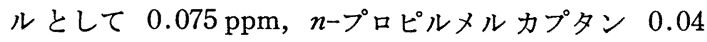
$\mathrm{ppm}$ であった。なお,この分析条件では二酸化硫黄と硫 化メチルは分離しないので,それぞれの換算值で表した。

浸出液からの二酸化硫黄の濃度が低いのは, 工程が開 放型であるためと考えられた。

本工程からは, 硫化水素, メチルメルカプタンが多く 排出されていることがわかった。

\section{2 完全自動化工場排気ガスの分析例}

グルテンフィード乾燥機からの排気ガスのガスクロマ トグラムの 1 例を Fig.-2 に, 定量結果を Table-2 に 示した。その結果, 3.1 と同様に硫化カルボニル, 硫化 水素, メチルメルカプタン, 二酸化硫黄（または硫化メ チル）などを同定した。

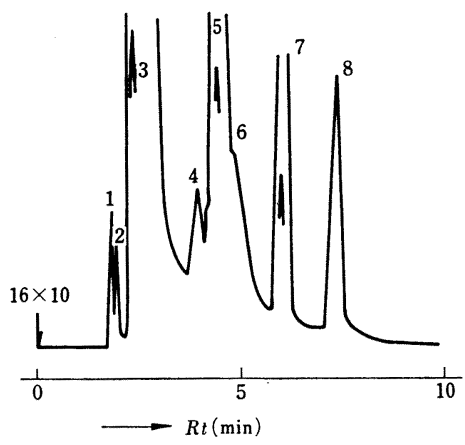

$25 \%$ TCEP on Shimalite (AW, DMCS) $60 / 80$ mech, $3 \mathrm{~mm} \phi \times 3 \mathrm{~m}$ glass, Temp. ; Column $50^{\circ} \mathrm{C}$, Inj. $70^{\circ} \mathrm{C}$, Det. $198^{\circ} \mathrm{C}$, Carrier gas; $\mathrm{N}_{2} 50 \mathrm{ml} / \mathrm{min}$ Precolumn; $4 \mathrm{~mm} \phi \times 31 \mathrm{~cm}$ (TCEP), Programming temp. $-183 \sim 100^{\circ} \mathrm{C} / 2.5 \mathrm{~min}$

1. $\mathrm{CO}_{2}$, 2. COS, 3. $\mathrm{H}_{2} \mathrm{~S}$ (atten. $1024 \times 1$ ), 4 . $\mathrm{CS}_{2}, 5 . \mathrm{CH}_{3} \mathrm{SH}$ (atten. $1024 \times 10$ ) 6. $\mathrm{C}_{2} \mathrm{H}_{5} \mathrm{SH}$, iso- $\mathrm{C}_{8} \mathrm{H}_{7} \mathrm{SH}$, tert $-\mathrm{C}_{4} \mathrm{H}_{8} \mathrm{SH}$, 7. $\mathrm{SO}_{2},\left(\mathrm{CH}_{8}\right)_{2} \mathrm{~S}$ (atten. $128 \times 10$ ) 8. $n-\mathrm{C}_{3} \mathrm{H}_{7} \mathrm{SH}$

Fig.-1 Gas chromatogram of lower sulfur compounds from an unautomated corn starch factory. (Sample concentration $0.5 l$ )

Table-1 Analyses data of representative lower sulfur compounds from an unautomated corn starch factory (2 samples).

\begin{tabular}{l|l|l}
\hline & \multicolumn{1}{|c|}{ ppm $\quad$ Range } & Ave. \\
\hline $\mathrm{COS}$ & $0.02 \sim 0.03$ & 0.025 \\
$\mathrm{H}_{2} \mathrm{~S}$ & $0.5 \sim 2.1$ & 1.3 \\
$\mathrm{CS}_{2}$ & 0.01 & 0.01 \\
$\mathrm{CH}_{8} \mathrm{SH}$ & $0.3 \sim 0.6$ & 0.45 \\
$\mathrm{SO}_{2},\left(\mathrm{CH}_{8}\right)_{2} \mathrm{~S}$ & $0.1 \sim 0.3\left(\right.$ as $\left.\mathrm{SO}_{2}\right)$ & 0.2 \\
& $0.05 \sim 0.1\left(\right.$ as $\left.\left(\mathrm{CH}_{8}\right)_{2} \mathrm{~S}\right)$ & 0.075 \\
$n-\mathrm{C}_{8} \mathrm{H}_{7} \mathrm{SH}$ & $0 \sim 0.08$ & 0.04 \\
\hline
\end{tabular}

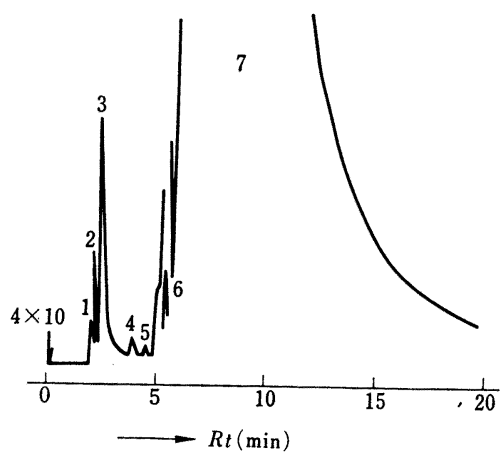

GC conditions same as Fig. -1

1. $\mathrm{CO}_{2}$, 2. COS, 3. $\mathrm{H}_{2} \mathrm{~S}, 4 . \mathrm{CS}_{2}, 5 . \mathrm{CH}_{8} \mathrm{SH}$, 6. $\mathrm{C}_{2} \mathrm{H}_{5} \mathrm{SH}$, iso- $\mathrm{C}_{8} \mathrm{H}_{7} \mathrm{SH}$, tert $-\mathrm{C}_{4} \mathrm{H}_{9} \mathrm{SH}(16 \times 10)$, 7. $\mathrm{SO}_{2},\left(\mathrm{CH}_{3}\right)_{2} \mathrm{~S}$.

Fig.-2 Gas chromatogram of lower sulfur compounds from an automated corn starch factory. (sample concentration $0.1 l$ )

Table-2 Analyses data of representative lower sulfur compounds from an automated corn starch factory. (3 samples)

\begin{tabular}{l|c}
\hline & ppm \\
\hline $\mathrm{COS}$ & 0.02 \\
$\mathrm{H}_{2} \mathrm{~S}$ & 0.02 \\
$\mathrm{CS}_{2}$ & 0.004 \\
$\mathrm{CH}_{8} \mathrm{SH}$ & 0.01 \\
$\mathrm{SO}_{2},\left(\mathrm{CH}_{8}\right)_{2} \mathrm{~S}$ & $>680\left(\right.$ as $\left.\mathrm{SO}_{2}\right)$ \\
\hline
\end{tabular}

前述のように二酸化硫黄と硫化メチルが分離しないが 本工程からは刺激臭のみが強く感じられいわゆる硫黄系 悪臭はほとんど感じなかったことから硫化メチルの共存 はほとんどないものと考え二酸化硫黄として定量した。

その結果, $680 \mathrm{ppm}$ 以上といら高濃度が検出された。 しかし, 前述悪臭物質（硫化水素およびメチルメルカプ タン）は極微量であった。すなわち, 検出濃度は平均 で, 硫化カルボニル $0.02 \mathrm{ppm}$, 硫化水素 $0.02 \mathrm{ppm}$, 二 硫化炭素 $0.004 \mathrm{ppm}$ ，メチルメルカプタン $0.01 \mathrm{ppm}$, 二酸化硫黄として $680 \mathrm{ppm}$ 以上であった。

なお, 本工程においては, それぞれの物質の濃度変化 はほとんどなかった。また，二酸化硫黄が高濃度検出さ れたことからこのピークの中に他のいくつかの成分がカ バーされていることも考えられるが，今回の実験では迅 速分析を目的としたので，分析条件の改善による分離向 上については検討しなかった。（昭和 49 年 8 月 8 日受理）

\section{文献}

1） R.L. デュプレイ著, 燃料協会訳 “大気污染物質の発生源 一発生過程と排出係数”, p. 23 (1971), 横川

2) H. Runge, Die Stärke, 24, 416 (1972)

3）二国二郎編集 “デンプンハンドブッグ” p. 498 (1961) 朝倉

4）星加安之, 角脇 怜, 小島一郎, 小池一美, 吉本健二, 分析化学, 23, 917 (1974) 